
\title{
25 Research Square \\ Effects of vitamin D supplementation on depression in patients with colorectal cancer
}

\author{
JianWen Duan \\ Hospital of Quzhou \\ YongSheng Chen \\ quhua hospital \\ WenFei Wu \\ Quzhou University \\ Cong Xiong \\ quhua hospital \\ ZuLiang Hu \\ quhua hospital \\ wenyu chen ( $\sim$ 1984423@163.com ) \\ Jiaxing University \\ Yufen XU \\ First Hospital of Jiaxing
}

Research

Keywords: Vitamin, Depression, Colorectal cancer

Posted Date: February 6th, 2020

DOI: https://doi.org/10.21203/rs.2.22782/v1

License: (c) (1) This work is licensed under a Creative Commons Attribution 4.0 International License.

Read Full License 


\section{Abstract}

Background: The relation and possible mechnism of vitamin D supplementation on depression in colorectal cancer (CRC) patients was not clearly ; Objective: This study investigates the effect of vitamin D supplementation on depression in colorectal cancer (CRC) patients. Methods : We recruited $168 \mathrm{CRC}$ patients and 168 healthy control subjects into this study. 17-item Hamilton Depression Rating Scale (HDRS-17) was used to assess depression. Results: We found that 25-hydroxyvitamin D (25(OH)D) concentrations were independently associated with depression among CRC patients. For the 45 depressed patients receiving vitamin D3 supplementation, depression scores decreased markedly with 25(OH)D concentrations increasing to normal. Conclusion: Therefore, we advise monitoring this indicator in CRC patients and supplementing with vitamin D 3 when their $25(\mathrm{OH}) \mathrm{D}$ concentrations are low.

\section{Background}

Depression is an extremely frequent complication among survivors of colorectal cancer (CRC), with prevalence ranging from $24-57 \%$. [1, 2] Depressive complication has been related to reduced quality of life[3] and increased mortality.[4]

The profuseness of vitamin $D$ receptors and vitamin $D$ activating enzyme 1a-hydroxylase in the center nervous system suggests involvement of vitamin $D$ in certain psychological processes.[5] Low concentrations of vitamin $\mathrm{D}$ have been associated with depression in both clinical and healthy populations.[6, 7]Moreover, recent prospective studies and clinical randomized controlled trials (RCT) have demonstrated positive effects of vitamin D supplementation on depression. $[8,9]$

Vitamin D deficiency is extremely frequent complication among CRC patients.[10 ]Low concentrations of vitamin $D$ have been related to increased mortality among survivors of CRC.[11]Moreover, recent studies have demonstrated a positive effect of vitamin $D$ supplementation on prognosis of CRC survivors.[12]. Base on both the involvement of vitamin $D$ in depression in non-CRC individuals and high prevalence of vitamin D deficiency in CRC patients, whether vitamin D supplementation exerts positive effects on depression in CRC patients was examined.

\section{Method}

\section{Study population and design}

We prospectively recruited 168 outpatients with CRC in the clinics of two facilities in Zhejiang QuHua Hospital and First Affiliated Hospital of Jiaxing University to participate in this study during the period from May 1, 2016, and October 10, 2018. Eligibility criteria were: (1) Chinese ethnicity; (2) aged 18 years or older; (3) having a diagnosis of CRC in their medical record; (4) having willingness to give written informed consent. Exclusion criteria were: (1) patients with cognitive dysfunction; (2) patients with hypercalcaemia, alone or together with hyperparathyroidism; (3) patients with a history of mental or 
psychological disease. Meantime, 168 age- and sex-matched healthy volunteers, without pre-existing vitamin D3 supplementation, were consecutively recruited from a health survey. Qualified patients were included into the cross-sectional study to evaluate the correlation between vitamin $\mathrm{D}$ concentrations and depression. Patients without sufficient 25-hydroxyvitamin D $(25(\mathrm{OH}) \mathrm{D})(\leq 75 \mathrm{nmol} / \mathrm{L})$ received vitamin D3 supplementation (cholecalciferol) $2000 \mathrm{IU} / \mathrm{d}$ for six months. According to whether there existed depression, we stratified patients into subgroups further. Regular follow-up visits were carried out after 3 months (T1) and 6 months (T2). Written informed consents were obtained from all participating subjects. The study was approved by the Ethics Committee of Zhejiang QuHua Hospital and all methods were conducted in compliance with our local guidelines and clinical regulations.

\section{Clinical assessment}

Depressive symptoms were screened using the 17-item Hamilton Depression Rating Scale (HDRS-17).[13] Patients with a HDRS-17 score of $\geq 7$ were given the Chinese version of Structured Clinical Interview for Depression (SCID) and Statistical Manual of Mental Disorders, 4th edition, to make a proper diagnosis. Pain intensity was assessed using a numerical rating scale from 10 to 0 , with 10 for "extremely painful" and 0 indicating "no pain". Social support was examined by two items as follows: (1) When suffering from worries, would you like to pour them to somebody (using a numerical rating scale from 1 to 4: 1 never; 2 only pouring my worries to my spouse or parents; 3 when my friends and relatives asking me, I will pour my worries to them; 4 pouring my worries to others on my own initiative)? (2) When suffering from difficulties, would you like to ask help from others (using a numerical rating scale from 1 to $4: 1$ never; 2 occasionally; 3 sometimes; 4 always)? Social support of patients was evaluated by the total scores from 2 to 8, with high score indicating good social status. Serum 25(OH)D, an optimal indicator of vitamin $\mathrm{D}$ metabolic condition, was measured using the competitive protein-binding assay with the intraassay coefficients of variation of $7-10 \%$.

\section{Outcome measure}

The primary outcome evaluated absolute changes in HDRS-17 scores after 3 and 6 months of vitamin D treatment. For the HDRS-17, the widely-accepted definitions of response (at least a $50 \%$ reduction from baseline in the total score) were adopted in this study.[14]

\section{Statistical analysis}

Categorical variables were compared using Pearson $\chi^{2}$ test. Fisher's exact test was performed instead if any of expected counts were $<5$. Student's $t$ test was performed for normally distributed variables, while Mann-Whitney $U$ test used was for parametric variables. Serum concentrations of $25(\mathrm{OH}) \mathrm{D}$ were divided into four quartiles ( $\leq 30.0,30.1-43.0,43.1-55.0$ and $\geq 55.1 \mathrm{nmol} / \mathrm{L}$ ), because the raw vitamin $\mathrm{D}$ data were skewed. Conditional logistic regression including those factors with $p<0.10$ in the univariate analysis was used to examine which variables were independently associated with depressive disorders. Linear mixed models were used to analyze the repeated measurements with missing values. The results were expressed as adjusted odds ratios (OR) with the corresponding $95 \%$ confidence intervals $(\mathrm{Cl})$. All 
statistical calculations were performed using SPSS for Windows, version 19.0 (SPSS Inc., Chicago, IL, USA). Concentration of statistical significance was defined as $p<0.05$.

\section{Results}

A total of 168 patients were enrolled in the present study. A total of 53 patients ( $31.5 \%, 36$ men, 17 women) were diagnosed with depression. CRC patients showed markedly lower serum concentrations of 25-hydroxyvitamin D (25(OH)D) as compared to normal controls ( $45.12 \pm 15.45$ vs. $63.14 \pm 16.46 \mathrm{nmol} / \mathrm{L}$, $\mathrm{p}<0.001)$. No correlation was found between $25(\mathrm{OH}) \mathrm{D}$ and age and gender in patients with CRC. Patients with depression had poorer financial situation, less social support and more pain. Significant differences were found between patients with depression and those without depression in 25(OH)D concentration quartiles of CRC patients $(p<0.001)$. The proportion of patients in the lowest quartile $(\leq 30.0 \mathrm{nmol} / \mathrm{L})$ was significantly higher in the depression group $(p<0.001)$, while the proportion of patients in higher quartiles (43.1-55.0 and $\geq 55.1 \mathrm{nmol} / \mathrm{L})$ was markedly lower in the depression group $(p<0.001$ and $p=$ 0.011 , respectively) (Table 1 ). 
Table 1

Demographic and clinical characteristics of the samples under study

\begin{tabular}{|c|c|c|c|}
\hline Variables & $\begin{array}{l}\text { Depressed } \\
(n=53)\end{array}$ & $\begin{array}{l}\text { Not depressed } \\
(n=115)\end{array}$ & $P$ value \\
\hline \multicolumn{3}{|l|}{ Sex } & 0.088 \\
\hline Male & $36(67.9)$ & $92(80.0)$ & \multirow[b]{3}{*}{0.398} \\
\hline Female & 17(32.1) & 23(20.0) & \\
\hline \multicolumn{3}{|l|}{ Age } & \\
\hline$\leq 50$ year & 18(43.0) & $37(32.2)$ & \\
\hline $50-60$ years & $24(45.3)$ & \multirow{2}{*}{$\begin{array}{l}43(37.4) \\
35(30.4)\end{array}$} & \\
\hline$\geq 60$ years & $11(20.8)$ & & \\
\hline Education & & & \multirow[t]{3}{*}{0.443} \\
\hline \multirow{2}{*}{$\begin{array}{l}\leq 6 \text { years } \\
>6 \text { years }\end{array}$} & $35(66.0)$ & $73(63.5)$ & \\
\hline & 18(34.0) & $42(36.5)$ & \\
\hline \multirow{2}{*}{$\begin{array}{l}\text { Financial situation } \\
\text { Poor }\end{array}$} & & & 0.013 \\
\hline & $34(62.4)$ & \multirow{2}{*}{$\begin{array}{l}50(43.5) \\
65(56.5)\end{array}$} & \multirow[b]{3}{*}{0.743} \\
\hline Satisfactory & 19(35.8) & & \\
\hline \multicolumn{3}{|l|}{ Marital status } & \\
\hline Married & $49(92.5)$ & 108(93.9) & \multirow[b]{3}{*}{0.993} \\
\hline Not married & $4(7.5)$ & $7(6.1)$ & \\
\hline \multicolumn{2}{|l|}{ Number of children } & & \\
\hline 0 & $8(15.1)$ & 15(13.0) & \multirow[b]{4}{*}{0.342} \\
\hline 1 & $14(26.4)$ & $32(27.8)$ & \\
\hline$>1$ & $31(58.5)$ & $68(59.1)$ & \\
\hline \multicolumn{2}{|l|}{ Living situation } & & \\
\hline \multirow{2}{*}{$\begin{array}{l}\text { With spouse and children } \\
\text { Other living situation }\end{array}$} & $41(77.4)$ & $96(83.5)$ & \multirow[b]{3}{*}{$<0.001$} \\
\hline & $12(22.6)$ & 19(16.5) & \\
\hline $\begin{array}{l}\text { Social support } \\
<4\end{array}$ & & & \\
\hline
\end{tabular}




\begin{tabular}{|c|c|c|c|}
\hline Variables & $\begin{array}{l}\text { Depressed } \\
(n=53)\end{array}$ & $\begin{array}{l}\text { Not depressed } \\
(n=115)\end{array}$ & $P$ value \\
\hline \multirow[b]{3}{*}{$>6$} & $30(56.6)$ & 24(20.9) & \multirow{2}{*}{$\begin{array}{l}<0.001 \\
<0.001\end{array}$} \\
\hline & $13(24.5)$ & $70(60.9)$ & \\
\hline & 10(18.9) & 21(18.3) & 0.925 \\
\hline Cancer stage & & & \multirow[t]{2}{*}{0.332} \\
\hline \multirow{2}{*}{$\begin{array}{l}\text { Duke's A or B } \\
\text { Duke's C or D }\end{array}$} & $25(46.3)$ & $44(38.3)$ & \\
\hline & $29(53.7)$ & 71(61.7) & \multirow[b]{2}{*}{0.447} \\
\hline Duration of CRC & & & \\
\hline$<1$ year & $20(37.7)$ & \multirow{3}{*}{$\begin{array}{l}35(30.4) \\
62(53.9) \\
18(15.7)\end{array}$} & \multirow[b]{4}{*}{0.552} \\
\hline $1-2$ years & $23(43.4)$ & & \\
\hline$>3$ years & 10(18.9) & & \\
\hline $\begin{array}{l}\text { Cancer treatments } \\
\text { Surgery, yes }\end{array}$ & $50(94.3)$ & 104(91.7) & \\
\hline Chemotherapy, yes & $44(83.0)$ & 91(79.1) & 0.556 \\
\hline Radiation, yes & 10(18.9) & $24(20.9)$ & 0.764 \\
\hline Other, yes & $2(3.8)$ & $3(2.6)$ & 0.651 \\
\hline \multicolumn{2}{|l|}{ Pain } & & $<0.001$ \\
\hline No & $19(38.5)$ & $82(71.3)$ & \multirow[b]{3}{*}{$<0.001$} \\
\hline Yes & $34(64.2)$ & $33(28.7)$ & \\
\hline $25(\mathrm{OH}) \mathrm{D}$ & & & \\
\hline Quartile 1 & $26(49.1)$ & $13(11.3)$ & $<0.001$ \\
\hline Quartile 2 & 19(35.8) & $28(24.3)$ & \multirow{2}{*}{$\begin{array}{l}0.123 \\
<0.001\end{array}$} \\
\hline Quartile 3 & $4(7.5)$ & $46(40.0)$ & \\
\hline Quartile 4 & $4(7.5)$ & $28(26.1)$ & 0.011 \\
\hline
\end{tabular}

In logistic regression analysis, serum 25(OH)D concentrations ( $\leq 30.0$ and $\geq 43.1 \mathrm{nmol} / \mathrm{L}$ ) were independently associated with the presence of depression among CRC patients (OR, 8.840;95\% Cl, $2.462-31.734, p=0.001$ and $\mathrm{OR}, 0.031 ; 95 \% \mathrm{Cl}, 0.008-0.124, \mathrm{p}<0.001$, respectively). Additionally, less 
social support and pain were markedly associated with the presence of depression among CRC patients (OR, 4.351; 95\% Cl, 1.324-14.303, $p=0.015$; OR, 6.358; 95\% Cl, 1.607-25.156, $p=0.008$, respectively).

We excluded 38 patients for not meeting the predetermined supplementation criteria $(n=19)$ or because they declined our invitation ( $n=19)$. Consequently, 130 (45 with and 85 without depression), began to take 2000 IU vitamin D3 per day for six months. Of these patients, the baseline characteristics were similar to those of the entire cohort. We observed reductions in HDRS-17 scores in depressed patients after 3 ( 9 vs. $12, p<0.001)$ and 6 months (8 vs. 12, p<0.001). There was no change being observed in non-depressed patients (Fig. 1). The treatment response was consistent with the restoration of vitamin D concentrations, which increased to normal after 3 and 6 months in patients with (75.13 and $75.47 \mathrm{nmol} / \mathrm{L}$, respectively) and without depression (76.71 and $77.07 \mathrm{nmol} / \mathrm{L}$, respectively) $($ all $\mathrm{p}<0.001)$. Specifically, we observed significant improvements (at least a $50 \%$ reduction from baseline in the total HDRS scores) in the majority of depressed patients after both 3 and 6 months.

\section{Discussion}

To our knowledge, this is the first report investigating the possible effects of vitamin D supplementation on depression in CRC patients. Our results suggest that serum concentrations of vitamin D were significantly associated with the presence of depression among CRC patients and vitamin D supplementation can improve depression in most CRC patients, which might have significant implications in providing novel proposal for the prevention and treatment of depressive complication in CRC patients.

We observed that serum concentrations of vitamin D were independently related to the presence of depression in CRC patients. Moreover, we found that the correction of vitamin D inadequacy exerts positive effects on depression in CRC patients. Caroline[9 ]found vitamin D supplementation significantly ameliorated depressive symptoms in women with chronic liver disease. Meanwhile, one randomized controlled trial showed vitamin D therapy was effective in decreasing perinatal depression concentrations.[8]

The exact role of vitamin $D$ in the pathophysiology of depression remains unknown. A possible explanation is the neuroprotective role for vitamin D via its effects on inflammatory response. A growing body of evidences has supported an important role of cytokines in the pathophysiology of depression.[15, 16] CRC patients have increased serum concentrations of the cytokines mentioned above.[17] Vitamin D plays a key role in modulating the secretion of cytokines.[18] Vitamin D may modulate the association of depression and inflammation via its role in the immune system.[19, 20]

There are several limitations in this study. First, the effect of other potential factors on serum vitamin D concentrations, such as lifestyle changes, dietary intake, and seasonal variation, was not considered in this study. Second, the present study was not an RCT, a design we avoided owing to ethical concerns, as we were unwilling to withhold treatment for vitamin D inadequacy. Finally, the fluctuating characteristic of vitamin D makes it preferable to complete all measurements on the same day. 


\section{Conclusion}

The results demonstrate depression was independently correlated with vitamin D concentrations in CRC patients. A therapeutic vitamin D supplementation may be recommended in CRC patients with low concentrations of vitamin D. Larger RCTs should be encouraged to confirm this study.

\section{Declarations}

\section{Acknowledgements}

The study investigators would like to acknowledge Han Bin for his contribution to the development of the study protocol.

\section{Author Contributions}

Study concept and design, D.-J.W and C.-W.Y. Acquisition of data, C.-Y.S., W.-W.F. and X.-C. H.-Z.L.Analysis and interpretation of data, D.-J.W. C.-W.Y. and W.-W.F. All authors read and approved the final manuscript.

\section{Competing Interests}

All authors declare that they have no competing interests.

\section{Ethics Approval And Consent To Participate}

The research was reviewed and approved by ZheJiang QuHua Hospital and the First Affiliated Hospital of Jiaxing University Ethics committee. Written informed consent was obtained from all participants.

\section{Availability Of Data And Materials}

The authors claim that consent has been received for each patient enrolled, and that in this article patients' personal data do not appear.

\section{Competing Interests}

There is no conflict of interest in this study, including financial,personal or any other potential conflict.

\section{Funding}

This work was funded by a grant from the QuZhou Municipal Sci-Tech Bureau Program (2019106) and Clinical Research Project in Medical Committee of Zhejiang Province (No. 2013ZYC-A89),the Key

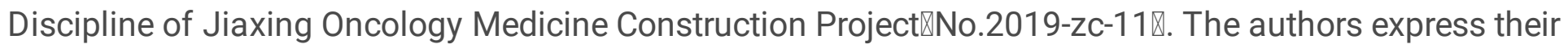
gratitude to all subjects who participated in the current study.

\section{References}


1. Shaheen Al Ahwal M, Al Zaben F, Khalifa DA, Sehlo MG, Ahmad RG, Koenig HG. Depression in patients with colorectal cancer in Saudi Arabia. Psycho-oncology. 2015 Sep;24(9):1043-50. PubMed PMID: 25328130.

2. Alacacioglu A, Binicier O, Gungor O, Oztop I, Dirioz M, Yilmaz U. Quality of life, anxiety, and depression in Turkish colorectal cancer patients. Supportive care in cancer : official journal of the Multinational Association of Supportive Care in Cancer. 2010 Apr;18(4):417-21. PubMed PMID: 19554353.

3. Akyol M, Ulger E, Alacacioglu A, Kucukzeybek Y, Yildiz Y, Bayoglu V, et al. Sexual satisfaction, anxiety, depression and quality of life among Turkish colorectal cancer patients [Izmir Oncology Group (IZOG) study]. Japanese journal of clinical oncology. 2015 Jul;45(7):657-64. PubMed PMID: 25862825.

4. Mols F, Husson O, Roukema JA, van de Poll-Franse LV. Depressive symptoms are a risk factor for allcause mortality: results from a prospective population-based study among 3,080 cancer survivors from the PROFILES registry. Journal of cancer survivorship : research and practice. 2013 Sep;7(3):484-92. PubMed PMID: 23677523.

5. Eyles DW, Smith S, Kinobe R, Hewison M, McGrath JJ. Distribution of the vitamin D receptor and 1 alpha-hydroxylase in human brain. Journal of chemical neuroanatomy. 2005 Jan;29(1):21-30. PubMed PMID: 15589699.

6. Barbonetti A, Cavallo F, D'Andrea S, Muselli M, Felzani G, Francavilla S, et al. Lower Vitamin D Levels Are Associated With Depression in People With Chronic Spinal Cord Injury. Archives of physical medicine and rehabilitation. 2017 May;98(5):940-6. PubMed PMID: 27986521.

7. Polak MA, Houghton LA, Reeder Al, Harper MJ, Conner TS. Serum 25-hydroxyvitamin D concentrations and depressive symptoms among young adult men and women. Nutrients. 2014 Oct 28;6(11):4720-30. PubMed PMID: 25353666. Pubmed Central PMCID: 4245559.

8. Vaziri F, Nasiri S, Tavana Z, Dabbaghmanesh MH, Sharif F, Jafari P. A randomized controlled trial of vitamin D supplementation on perinatal depression: in Iranian pregnant mothers. BMC pregnancy and childbirth. 2016 Aug 20;16:239. PubMed PMID: 27544544. Pubmed Central PMCID: 4992225.

9. Stokes CS, Grunhage F, Baus C, Volmer DA, Wagenpfeil S, Riemenschneider M, et al. Vitamin D supplementation reduces depressive symptoms in patients with chronic liver disease. Clinical nutrition. 2016 Aug;35(4):950-7. PubMed PMID: 26212170.

10. Ma K, Xu W, Wang C, Li B, Su K, Li W. Vitamin D deficiency is associated with a poor prognosis in advanced non-small cell lung cancer patients treated with platinum-based first-line chemotherapy. Cancer biomarkers : section A of Disease markers. 2017;18(3):297-303. PubMed PMID: 27983538.

11. Holick MF, Chen TC. Vitamin D deficiency: a worldwide problem with health consequences. The American journal of clinical nutrition. 2008 Apr;87(4):1080S-6S. PubMed PMID: 18400738.

12. Lewis $C, X u n ~ P, H e K$. Vitamin $D$ supplementation and quality of life following diagnosis in stage II colorectal cancer patients: a 24-month prospective study. Supportive care in cancer : official journal 
of the Multinational Association of Supportive Care in Cancer. 2016 Apr;24(4):1655-61. PubMed PMID: 26408324.

13. Hamilton M. A rating scale for depression. Journal of neurology, neurosurgery, and psychiatry. 1960 Feb;23:56-62. PubMed PMID: 14399272. Pubmed Central PMCID: 495331.

14. Bobo WV, Anglero GC, Jenkins G, Hall-Flavin DK, Weinshilboum R, Biernacka JM. Validation of the 17item Hamilton Depression Rating Scale definition of response for adults with major depressive disorder using equipercentile linking to Clinical Global Impression scale ratings: analysis of Pharmacogenomic Research Network Antidepressant Medication Pharmacogenomic Study (PGRNAMPS) data. Human psychopharmacology. 2016 May;31(3):185-92. PubMed PMID: 26999588. Pubmed Central PMCID: 5008690.

15. Vogelzangs N, Duivis HE, Beekman AT, Kluft C, Neuteboom J, Hoogendijk W, et al. Association of depressive disorders, depression characteristics and antidepressant medication with inflammation. Translational psychiatry. 2012 Feb 21;2:e79. PubMed PMID: 22832816. Pubmed Central PMCID: 3309556.

16. Song $\mathrm{C}$, Wang $\mathrm{H}$. Cytokines mediated inflammation and decreased neurogenesis in animal models of depression. Progress in neuro-psychopharmacology \& biological psychiatry. 2011 Apr 29;35(3):7608. PubMed PMID: 20600462.

17. Oliveira Miranda D, Soares de Lima TA, Ribeiro Azevedo L, Feres O, Ribeiro da Rocha JJ, Pereira-daSilva G. Proinflammatory cytokines correlate with depression and anxiety in colorectal cancer patients. BioMed research international. 2014;2014:739650. PubMed PMID: 25309921. Pubmed Central PMCID: 4182686.

18. Sommer A, Fabri M. Vitamin D regulates cytokine patterns secreted by dendritic cells to promote differentiation of IL-22-producing T cells. PloS one. 2015;10(6):e0130395. PubMed PMID: 26107738. Pubmed Central PMCID: 4480856.

19. van Etten E, Stoffels K, Gysemans C, Mathieu C, Overbergh L. Regulation of vitamin D homeostasis: implications for the immune system. Nutrition reviews. 2008 Oct;66(10 Suppl 2):S125-34. PubMed PMID: 18844839.

20. Mora JR, Iwata M, von Andrian UH. Vitamin effects on the immune system: vitamins A and D take centre stage. Nature reviews Immunology. 2008 Sep;8(9):685-98. PubMed PMID: 19172691. Pubmed Central PMCID: 2906676.

\section{Figures}




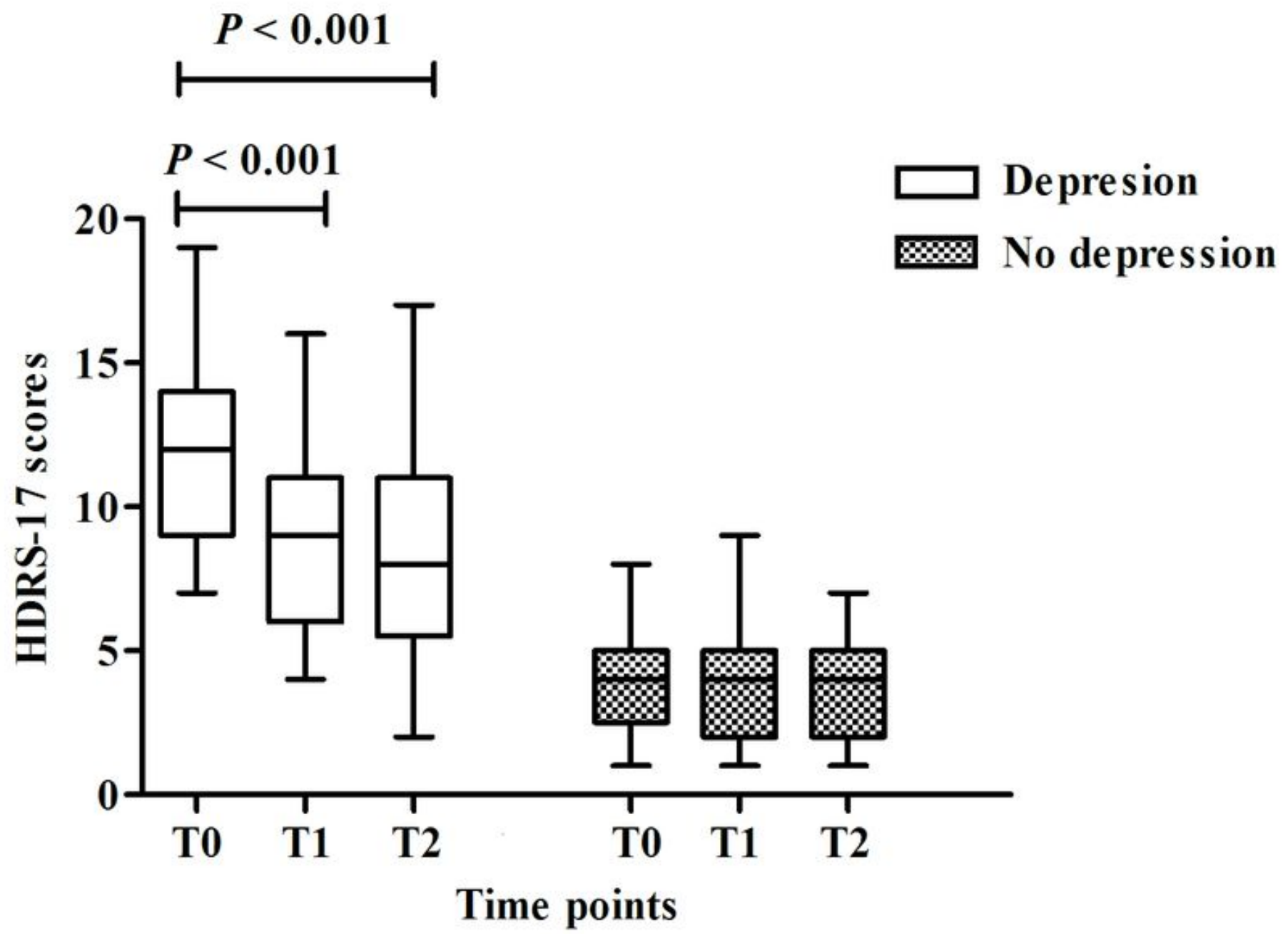

Figure 1

Changes in depression during the study 